\title{
ANALISIS PENGENDALIAN PIUTANG TERHADAP PENAGIHAN PIUTANG ARUS KAS PT.COWELL DEVELOPMENT TBK
}

\author{
Agustin \\ Sekolah Tinggi Ilmu Ekonomi Wiyatamandala \\ agustinutin326@gmail.com
}

\begin{abstract}
This study aims to analyze the control of receivables on the collection of cash flow receivables at PT.Cowell Development Tbk. The data analysis technique used in this research is descriptive qualitative method. Qualitative descriptive analysis is a data analysis technique that is done by collecting data, clarifying data, explaining and analyzing so that it provides information and images that are appropriate to the problem being faced or researched. Sources of data in the study used are secondary data sources and primary data. From the results of the study show that the control of receivables is the billing process with a long time to the bills that are due. PT. Cowell Development Tbk must be more active in the collection of receivables so that the balance of the amount of receivables is not too large so that it will affect the effectiveness of cash flow.
\end{abstract}

Keywords: Control of Receivables, Collection of Cash Flow Receivables

\section{PENDAHULUAN}

Seiring dengan bertambah pesatnya pertumbuhan ekonomi di Indonesia, banyak berdirinya berbagai jenis perusahaan mulai dari skala kecil hinga berskala besar baik itu perusahaan jasa, perusahaan dagang maupun perusahaan manufaktur. Piutang merupakan modal kerja yang diharapkan dapat memberikan tambahan penghasilan dan laba, oleh sebab itu adanya piutang memerlukan analisis yang cukup besar yang dapat merugikan perusahaan. Manajemen piutang memiliki peranan yang sangat penting kaitannya terhadap penilaian piutang, pencatatan piutang dan prosedur piutang sehingga dapat memberikan gambaran tentang untung ruginya di laksanakan dari jumlah piutang dan tingkat perputaran piutang yang dapat mengantispasi, memperkecil atau bahkan menghilangkan resiko yang akan mungkin terjadi dari piutang. Menurut Syukur (2015) piutang adalah adanya piutang timbul karena adanya pengakuan kepada pihak lain 
di waktu sebelumnya dalam bentuk uang, barang, jasa atau dalam bentuk piutang usaha yang harus dilakukan penagihan (collect) pada tanggal jatuh temponya. Piutang usaha merupakan tagihan yang terjadi karena adanya penjualan barang, jasa, atau penjualan aktiva lainnya yang dilakukan secara kredit dengan demikian dapat menimbulkan terjadinya piutang. Besar kecilnya jumlah piutang berpengaruh terhadap efektivitas arus kas. Menurut Downes (2006) arus kas adalah proses penerimaan dan pengeluaran kas dari semua kegiatan perusahaan, kegiatan pembiayaan atau pendanaan dalam kas suatu perusahaan selama periode. PT Cowell Development Tbk merupakan salah satu pengembangan kawasan residensial dan bangunan komersial terdepan di Indonesia. Untuk mendukung kegiatan perusahaan dalam meningkatkan laba PT. Cowell Development Tbk banyak melakukan perubahan dari administrasi proses pengiriman tagihan yang secara manual diubah dengan menggunakan sistem untuk mempermudah atau mempercepat proses kerja dalam pengiriman tagihan kepada customer untuk menghindari keterlambatan pembayaran yang dapat menimbulkan piutang dan akan berpengaruh terhadap efektivitas arus kas perusahaan. Berikut daftar saldo piutang pada PT.Cowell Development Tbk selama tahun 2015 sampai dengan 2017 sebagai berikut:

Tabel 1 Daftar Saldo Piutang Pada PT.Cowell Development Tbk

\begin{tabular}{ccc}
\hline Tahun & Saldo Piutang & Saldo Kas \\
2015 & $20,128,736,490$ & $49,380,689,764$ \\
2016 & $26,177,729,544$ & $21,186,936,762$ \\
2017 & $115,331,236,951$ & $28,855,932,186$ \\
\hline
\end{tabular}

Dari data diatas menunjukan bahwa saldo piutang mengalami kenaikan dari tahun 2015 sampai dengan tahun 2017, saldo kas dan setara kas mengalami penurunan dari tahun 2015 sampai dengan tahun 2017.
Jika dilihat dari data di atas adanya kenaikan saldo piutang dan apabila saldo piutang bertambah besar maka akan berpengaruh terhadap jumlah saldo kas. Pengelompokan piutang ke dalam kategori yang berdasarkan 
tanggal jatuh tempo piutang. Karakteristik umur piutang disini dapat dikelompokan menjadi bagian: belum jatuh tempo, telah jatuh tempo 0-60 hari, telah jatuh tempo 61-90 hari, telah jatuh tempo diatas 91 hari. Lamanya umur piutang yang telah jatuh tempo merupakan lamanya hari mulai saat piutang tersebut jatuh tempo hingga laporan umur piutang (aging account receivable). Piutang usaha diharapkan dapat tertagih dalam satu tahun atau siklus usaha normal dikelompokan sebagai aktiva lancar. Perusahaan menganggap seluru piutang usaha baik status piutang itu lancar dan tidak lancar, tetap diakui sebagai aktiva lancar. Dengan demikian jumlah piutang usaha yang jangka waktu

\section{TELAAH LITERATUR}

Menurut Martani (2012) piutang adalah suatu pengakuan piuang di perusahaan terhadap pihak lain. Piutang usaha dapat berupa tagihan yang timbul karena adanya penjualan barang dagang, jasa atau penjualan harta lainnya yang dilakukan secara kredit dan transaksi lain yang dapat menimbulkan pengakuan kepada pihak lain. Menurut Soemarso (2002) penagihannya lebih dari satu tahun atau siklus usaha normal harus diungkapkan dalam catatan atau laporan keuangan. Berdasarkan uraian diatas, peneliti tertarik untuk melakukan penelitian tentang sistem pengelolaan piutang pada PT. Cowell Developmeny Tbk dan adapun rumusan masalah yang dibahas dalam tulisan ini antara lain:

1. Tindakan apa yang dilakukan perusahaan dalam mengelola piutang?

2. Apakah pengelolaan terhadap piutang telah dilaksanakan dengan baik?

3. Kenapa jumlah piutang yang tak tertagih mengalami kenaikan?

piutang adalah adanya pengakuan hak terhadap pihak lain atau perusahaan untuk meminta hak pembayarannya dalam bentuk uang ataupun penyerahan harta atau jasa lainnya kepada pihak dengan siapa dia berkepentingan. Menurut Munir (2005) piutang adalah perusahaan memiliki hak penagihan piutang terhadap pihak lain yang menjadi pihak yang tertunggak dan berharap 
pembayaran dari mereka agar dapat memenuhi kewajibannya terhadap perusahaan. Jenis-jenis piutang dapat dibagi menjadi 3 bagian yaitu:

1. Piutang Usaha (Account Receivable)

Jumlah atau nominal yang akan ditagihkan kepada customer atas pembayaran yang dilakukan secara bertahap (dicicil). Piutang usaha yang jatuh tempo kurang dari 30 hari atau 60 hari biasanya dapat ditagih dengan waktu relatif cepat, dengan demikian di catat dalam pembukuan bahwa piutang usaha dikelompokan dalam neraca menjadi sebagai aset lancar (current asset).

2. Piutang Wesel (Notes Receivalbe)

Tagihan perusahaan kepada pembuat wesel. Pihak wesel yang berhutang kepada perusahaan melalui pembayaran barang atau jasa secara kredit maupun melalui pinjaman sejumlah uang.

3. Piutang Lain-lain (Other Receivable)

Piutang lain-lain pada dasarnya dikelompokan dan dilaporkan secara terpisah didalam neraca contohnya piutang bunga, piutang deviden (tagihan kepada investee sebagai hasil atas investasi dalam perusahaan), piutang pajak (tagihan perusahaan kepadda pihak pemerintah berupa pengembalian atas kelebihan pembayaran pajak perusahaan) dan tagihan kepada karyawan perusahaan. Piutang dikatakan aset lancar yaitu apabila piutang tersebut dapat ditagihkan dalam waktu satu tahun.

Sebuah perusahaan dalam menjalankan operasional perusahaan salah satunya adalah resiko piutang customer yang tidak dapat di tagihkan. Dalam akuntansi, timbulnya piutang tak tertagih. Menurut Zaki Baridwan (2004) piutang usaha adalah piutang yang sudah tidak dapat ditagihkan kepada pihak yang bersangkutan contohnya customer bangkrut, meninggal, pailit atau lain-lainnya sehingga piutang tersebut harus dihapuskan dan piutang tersebut menjadi biaya bagi 
perusahaan. Resiko yang terjadi dalam piutang usaha dalam suatu perusahaan diantaranya resiko tidak dibayarkannya seluruh piutang untuk perusahaan adalah resiko yang paling berat yang harus diterima perusahaan karena tagihan yang telah sesuai dengan yang direncanakan dan disusun untuk diterima dimasa yang akan datang ternyata tidak dapat diterima kembali sebagai kas atau sebagai pendapatan perusahaan. Resiko yang tidak dibayarkan sebagai piutang untuk perusahaan adalah resiko yang lebih mudah dibandingkan resiko tidak dibayarkan seluruh piutangnya karena sebagian dari jumlah piutang tersebut telah diterima oleh perusahaan menjadi kas atau pendapatan. Resiko keterlambatan pelunasan untuk perusahaan adalah resiko yang lebih mudah dari resiko tidak dibayarkan sebagai piutang tetapi bukan berarti tidak mempengaruhi keadaan didalam perusahaan karena dalam waktu yang tidak lama terbukti bahwa adanya pemasukan dari pembayaran tagihan tersebut telah melewati jadwal jatuh tempo tagihan. Prosedur pencatatan piutang bertujuan untuk mencatat mutasi piutang perusahaan kepada setiap customer. Mutasi piutang disebabkan oleh transaksi pembayaran secara kredit, penerimaan kas dari customer dan penghapusan piutang. Informasi mengenai piutang yang dilaporkan kepada manajemen sebagai berikut:

1. Saldo piutang setiap customer Pernyataan ini memberikan informasi tentang berapa banyak saldo piutang yang dimiliki oleh customer

2. Riwayat pelunasan piutang setiap customer

Pernyataan ini memberikan informasi atas riwayat pelunasan setiap customer atas pelunasan tagihan yang pernah dimiliki atau tagihan yang tertunggak.

3. Umur piutang setiap customer.

Pernyataan ini memberikan informasi tentang umur piutang atas setiap customer untuk kedepannya agar setiap customer tidak memiliki umur piutang yang panjang atau yang lama. 


Beberapa teknik yang dapat
digunakan untuk meningkatkan
penagihan terhadap piutang yang
jatuh tempo. Teknik-teknik
penagihannya sebagai berikut:

1. Follow-up by Telepon

Apabila customer belum melakukan pembayaran atas tagihan yang sudah jatuh tempo maka dilakkan followup by telepon karena untuk reminder customer agar segera melakukan pembayaran atas tagihan yang sudah jatuh tempo.

2. Surat peringatan

Apabila customer belum melakukan pembayarannya maka dalam waktu telat 1 bulan, akan dikeluarkan surat peringatan atas tagihan yang sudah jatuh tempo.

3. Mendatangi langsung penyewa atau customer

Apabila customer masih belum melakukan kewajiban melakukan pembayaran makan dilakukan mendatangi penyewa atau customer untu ditindaklanjuti atas kewajiban penyewa bekum melakukan kewajibannya untuk melunasi tagihan yang sudah jatuh tempo.

Perputaran piutang usaha didalam perusahaan menjadi tolak ukur untuk dapat menganalisa atas piutang agar piutang tersebut dapat berubah menjasi kas. Adanya piutang usaha karena terjadinya pembayaran yang dilakukan secara kredit yang mengakibatkan adanya piutang tak tertagihh sesuai dengan demikian di kelompokan dalam daftar piutang tak tertagih sesuai dengan lamanya masing-masing. Nilai dari perputaran piutang usaha tergantung dari cara penagihan piutang apabila dalam penagihan piutang lama makan lama juga piutang tersebut menjadi kas. Menurut Bambang Riyanto (2004) Perputaran piutang usaha adalah dimana pada saat kas dikeluarkan untuk mendapatkan persediaan, lalu kemudian persediaan dijual secara kredit sehingga mengakibatkan terjadinya piutang dan piutang berubah menjadi kas pada saat penerimaan pelunasan piutang dari customer. Semakin cepat perputaran piutang usaha dalam perusahaan, maka semakin efektif perusahaan dalam mengelola piutang usahanya. 
Likuiditas dari piutang usaha yang dapat diketahui melalui analisis rasio perputaran piuang usaha (receivable turnover ratio) perputaran piutang usaha menunjukan beberapa kali piutang usaha perusahaan berputar dalam satu tahun. Perputaran piutang usaha dapat dihitung dengan rumus:

$$
\text { Perputaran Piutang Usaha }=\frac{\text { Penjualan Pada Kredit Bersih }}{\text { Saldo Rata }- \text { Rata Piutang Usaha }}
$$

Untuk menghitung rata-rata piutang

sebagai berikut :

usaha maka dapat dirumuskan

\section{Saldo Awal Piutang Usaha + Saldo Akhir Piutang Usaha

Semakin besar perputaran piutang usaha berarti semakin cepat pengembalian piutang usaha tersebut, perputaran piutang usaha menunjukan beberapa penjabaran, yaitu:

1. Jumlah modal yang diinvestasikan dalam bentuk piutang usaha sebelum dana berubah menjadi bentuk tunai atau kas. Semakin cepat perputaran piutang usahaakan semakin sedikit pula dana yang diinvestasikan dalam piutang usaha.

2. Bila perputaran piutang usaha lambat bisa disebabkan karena kinerja bagian penagihan kurang bagus atau customer mengulur waktu dari tanggal jatuh tempo.

3. Jika perusahaan memiliki kebijakan pembayaran secara kredit satu bulan tetapi perputaran piutang usaha menunjukan angka kredit dua atau tiga bulan, kemungkinan masalah terletak pada pelanggan yang tidak mampu atau tidak mau membayar.

4. Rata-rata jangka waktu penagihan menunjukan ratarata waktu yang diperlukan untuk mengumpulkan piutang usaha dalam suatu periode tertentu. Rata-rata jangka waktu penagihan dapat 
dihitung dengan rumus:

$$
\frac{360 \text { hari atau (1 Tahun) }}{\text { Perputaran Piutang Usaha }}
$$

Menurut Sodikin dan Riyono (2014) kas atau dikatakan cash adalah uang kertas dan uang logam dan sebagai alat pembayaran lainnya yang disamakan dengan uang tunai. Uang memiliki karakteristik untuk dialihkan atau dipindah tangankan, maka kas merupakan aktiva yang cenderung disalah gunakan. Di samping itu, banyak transaksi dari secara langsung atau tidak mempengaruhi penerimaan atau pembayaran kas. Perusahaan harus merancang kas serta wewenang pengendalian terhadap transaksi kas. Menurut Baridwan (2008) kas adalah sebagai alat pertukaran yang dapat diterima untuk pelunasan utang dan dapat diterima juga sebagai suatu setoran atau kegiatan ke bank dengan jumlah sebesar nominal yang akan disetor di bank dan melakukan simpanan uang dibank yang dapat diambil setiap waktu. Kas adalah harta yang paling likuid, kas sangat mudah menjadi objek penyalahgunaan kecuali jika dijaga dengan memadai. Apabila perusahaan dapat menerapkan pengendalian internalyang efektif, perusahaan dapat mengurangi peluang terjadinya pencurian, kerugian atau kesalahan yang tidak disengaja dalam akuntansi dan pengendalian kas. Maka dapat ditarik kesimpulan bahwa kas merupakan aset berbentuk uang maupun bukan uang yang dapat digunakan untuk membayar kewajiban perusahaan serta merupakan aset yang paling likuid atau paling lancar. Arus kas (cash flow) adalah suatu laporan keuangan yang meliputi pengaruh kas dari kegiatan operasional perusahaan, adanya kegiatan pembiayaan perusahaan atau pendanaan perusahaan dalam kas dan dalam perusahaan selama satu periode. Laporan arus kas merupakan dari mana uang kas diperoleh perusahaan dan bagaimana mereka mengelola arus kas tersebut. Laporan arus kas merupakan rangkuman dari penerimaan kas dan pengeluaran kas perusahaan selama periode tertentu (satu tahun pembukuan). Laporan 
arus kas memberikan informasi yang relevan tentang penerimaan dan pengeluaran kas dari perusahaan dari suatu periode tertentu dengan mengklarifikasikan transaksi berdasarkan pada kegiatan pendanaan. Laporan arus kas terdiri dari 3 aktivitas yaitu :

1. Aktivitas Operasional

Aktivitas operasional menimbulkan pendapatan dan beban dari operasional utama suatu perusahaan karena aktifitas operasional mempengaruhi laba rugi suatu perusahaan, yang dilaporkan dengan dasar penerimaan dan pengeluaran atau dicatat ketika transaksi terjadi, sedangkan laporan arus kas melaporkan dampaknya terhadap kas. Arus masuk kas terbesar dari operasional berasal dari pengumpulan kas dari customer. Arus masuk yang kurang penting adalah penerimaan bunga atas pinjaman dan dividen atas investasi saham. Arus kas operasional meliputi pembayaran terhadap pemasok dan karyawan, serta pembayaran bunga dan pajak.

2. Aktivitas Investasi

Aktivitas investasi perusahaan dalam alokasi dana kedalam bentuk aktiva tetap. Contohnya dengan pembelian aktiva tetap yang masa pakainya lebih dari satu tahun.

3. Aktivitas Pendanaan

Aktivitas pendaan perusaahaan dalam mencari tambahan modal usaha dalam pengembangan perusahaan tersebut.

Perusahaan dalam kegiatan bisnisnya akan ada customer yang melakukan pembayarannya secara kredit, maka perlu adanya suatu efektifitas dalam arus kas. Artinya, penerimaan atau pengeluaran kas perusahaan harus benar-benar sesuai dengan kegiatan bisnis yang dijalankan dalam perusahaan. Proses dalam penagihan ke customer bisa berpengaruh terhadap arus kas karena apabila penagihan tidak dilakukan dengan aktif maka customer juga akan semakin lama membayar tagihan dan dapat menimbulkan piutang. Apabila 
jumlah piutang semakin besar maka arus kas tidak efektif. Jenis-jenis rasio aktivitas dapat dibagikan menjadi beberapa bagian yaitu :

1. Tingkat perputaran piutang (Receivable Turn Over) adalah suatu angka yang menunjukan berapa kali (dalam rata-rata) suatu perusahaan melakukan tagihan atas piutangnya pada periode tertentu. Perputaran Piutang (receivable turn over) bagi perusahaan sangatlah penting untuk mengetahui karena makin tinggi perputaran piutang, maka piutang yang dapat ditagih oleh perusahaan semakin banyak. Sehingga akan memperkecil adanya piutang yang tak tertagih dan memperlancar arus kas. Adapun hasil perhitungan dari perputaran piutang usaha adalah sebagai berikut:

$$
R T O=\frac{\text { Credit Sales }}{\text { Average Receivable }}
$$

2. Rata-rata Penagihan Piutang

(Average

\section{Collection Periode)}

Rasio ini berfungsi untuk mengetahui berapa hari rata-rata penagihan piutang yang dilakukan. Rasio ACP ini ditunjukan dengan jumlah hari, semakin kecil jumlah harinya maka akan semakin baik, artinya perusahaan mampu menagih dengan cepat setiap piutang usahanya. Hasil yang ditetapkan dari perhitungan ini akan dihubungkan dengan jumlah hari yang ditetapkan sebagai standar kredit perusahaan.

$$
A C P=\frac{360 \mathrm{Hari}}{R T O}
$$


Umur Piutang (Aging of Account Receivable)

Suatu angka yang menunjukan untuk mengukur berdasarkan aging atau umur overdue piutang usaha. Semakin besar umur piutang usaha yang tidak bisa dibayarkan berarti semakin buruk kualitas account receivable tersebut dan berarti semakin besar kemungkinan piutang tak tertagihnya. Hasil perhitungan aging of account receivable dapat dilihat pada tabel berikut:

$$
\text { Aging of Account Receivable }=\frac{\text { Jumlah Piutang Tertagih }}{\text { Total Piutang }} \times 100 \%
$$

\section{METODE PENELITIAN}

Metode yang digunakan oleh penulis adalah metode deskriptif, yaitu penelitian yang menguraikan sifatsifat dan keadaan sebenarnya dari suatu objek penelitian. Tujuan dalam penelitian ini untuk mengumpulkan fakta dan menguraikannya secara menyeluruh dan teliti sesuai dengan persoalan yang akan dipecahkan. Peneliti membahas sistem pengendalian piutang terhadap efektifitas arus kas pada perusahaan PT Cowell Development Tbk. Data yang digunakan dalam penelitian ini adalah data primer. Data primer merupakan data yang diperoleh secara langsung dari sumber pertama yaitu pada PT Cowell Development Tbk. Data primer yang dikumpulkan adalah data dari tahun 2015-2017.
Data sekunder merupakan data pendukung yang bersifat memperkuat hasil analisa, data ini merupakan data yang sudah ada atau disusun oleh pihak perusahaan, berupa sejarah perkembangan perusahaan, deskripsi jabatan dan struktur organisasi. Adapun teknik analisis data yang digunakan dalam penelitian ini adalah metode deskriptif kualitatif. Analisis deskriptif kualitatif adalah teknik analisis data yang dilakukan dengan cara mengumpulkan data, mengklasifikasikan data, menjelaskan dan menganalisis sehingga memberikan informasi dan gambaran yang sesuai dengan masalah yang dihadapi atau diteliti. 
1. Receivable turn over (RTO)

perusahaan. Adapun hasil

RTO bertujuan untuk

perhitungan dari perputaran

mengukur likuiditas dan piutang usaha adalah sebagai aktifitas dari piutang berikut:

$$
R T O=\frac{\text { Credit Sales }}{\text { Average Receivable }}
$$

2. Average Collection Period (ACP)

ACP berfungsi untuk mengetahui rata-rata hari

$$
A C P=\frac{360 \mathrm{Hari}}{R T O}
$$

\section{Aging of account receivable}

$$
\begin{aligned}
& \text { Rasio ini berfungsi untuk } \\
& \text { mengukur komposisi bucket } \\
& \text { account receivable dalam }
\end{aligned}
$$

yang diperlukan untuk mengumpulkan piutang usaha dan mengubahnya menjadi kas.

\section{HASIL DAN PEMBAHASAN}

Prosedur pencatatan atas piutang PT Cowell Development Tbk dilakukan pengecekan setiap hari pada saat membuat report account receivable harian yaitu report account receivable Aging Summary Net Saldo untuk mengetahui berapa banyak yang sudah melakukan pembayaran atas tagihan dan berapa banyak yang masih belum melunasi tagihan. Setelah dilakukan penarikan report account receivable maka terdapat dua opsi diantaranya bila customer sudah melakukan pembayaran maka tidak dilakukan tindak lanjut ke customer. Melakukan tindak lanjut pembayaran apabila customer tersebut belum 
melunasi kewajibannya sebagai penyewa (belum melakukan pembayaran tagihan). Apabila dalam waktu 1 (satu) bulan dari waktu jatuh tempo tagihan customer tersebut belum melunasi kewajibannya maka akan diberlakukan pengeluran surat peringatan pertama (SP1). Apabila dalam 2 (dua) bulan setelah SP1 belum juga dibayarkan maka akan dikeluarkan surat peringatan kedua (SP2). Apabila setelah SP2 sudah dikeluarkan dan dalam jangka 3 (tiga) bulan dari waktu jatuh tempo tagihan customer tersebut belum melunasi kewajibannya maka akan di keluarkan surat peringatan (SP3), apabila sudah SP3 tidak juga dibayarkan maka akan dilakukan mengunjungi customer untuk melalukan atas penagihan atas tagihan yang tertunggak / outstanding pembayaran. Sistem pengendalian internal piutang adalah kumpulan dari pengendalian internal yang terintegrasi, berhubungan dan saling mendukung satu dengan yang lainnya. PT Cowell Development Tbk tentang pengendalian piutang terhadap penagihan piutang arus kasdengan cara membandingkan antara hasil penelitian yang diperoleh dengan landasan teori yang ada. Terdapat lima komponen pengendalian intern menurut COSO, yaitu lingkungan pengendalian, penentu risiko, aktivitas pengendalian informasi dan komonikasi serta pengawasan atau pemantauan pada PT Cowell Development Tbk yaitu sebagai berikut:

\section{Lingkungan Pengendalian} Internal Piutang.

Dasar dari komponen pengendalian yang lain secara umum dapat memberikan landasan disiplin salah satunya dengan gaya manajemen operasional.

\section{Penilaian Risiko atas Piutang}

Berdasarkan hasil penelitian dan wawancara pada PT Cowell Development Tbk penilaian resiko atas piutang usaha adalah untuk menghindari resiko terjadinya piutang dilakukan membuat report account receivable harian yaitu report account receivable aging summary net saldo untuk mengetahui berapa banyak yang sudah melakukan pembayaran 
atas tagihan dan berapa banyak yang masih belum melunasi tagihan.

3. Aktivitas Pengendalian atas Piutang.

$\begin{array}{lr}\begin{array}{l}\text { Kebijakan atas } \\ \text { pengendalian atas }\end{array} & \text { piutang } \\ \text { harus menetapkan } & \text { tanggung } \\ \text { jawab berbagai } & \text { macam } \\ \text { aktivitas usaha. } & \text { Tanggung } \\ \text { jawab untuk operasional, } & \text { dipisahkan } \\ \text { penangan aset perusahaan dan } \\ \text { akuntansi harus } \\ \text { untuk dapat mengurangi } \\ \text { kemungkinan terjadinya }\end{array}$
kesalahan dan kecurangan. Catatan akuntansi akan sangat berpengaruh sebagai peran penting sebagai pemeriksaan independen atas perorangan yang bertanggung jawab atas penyimpanan aset dan yang bertanggung jawab atas operasional usaha perusahaan.

4. Informasi dan komunikasi atas piutang

Informasi dan komunikasi merupakan elemen yang penting dari pengendalian internal perusahaan. Informasi tentang lingkungan pengendalian, penilaian resiko, prosedur pengendalian dan monitoring dibutuhkan manajemen perusahaan untuk mengarahkan operasional dan memastikan kepatuhan pada pelaporan, hukum dan peraturan yang diperlukan. PT Cowell Development Tbk juga dapat menggunakan informasi ekstrenal untuk menilai kejadian dan kondisi perusahaan yang dapat berpengaruh pada pengambilan keputusan dan pelaporan eksternal.

5. Pengawasan dan Pemantauan Piutang.

$\begin{array}{lcr}\text { Manajemen } & \text { PT } & \text { Cowell } \\ \text { Development } & \text { Tbk } & \text { telah } \\ \text { menggariskan } & \text { tugas } & \text { dan }\end{array}$
tanggung jawab kepada masingmasing bagiannya secara jelas. Kelancaran piutang usaha menjadi tanggung jawab bagian finance dan accounting, karena setiap bagian mempunyai tugas dan tanggung jawab yang sudah di tentukan oleh manajemen perusahaan. 
Tabel 2 Saldo Piutang Usaha Tahun 2015 PT.Cowell Development Tbk

\begin{tabular}{cc} 
Umur Piutang usaha & Saldo Piutang Usaha \\
Belum Jatuh Tempo & Rp 17,364,650,232 \\
Jatuh Tempo 31-60 hari & $\operatorname{Rp~1,647,107,120~}$ \\
Jatuh Tempo 61-90 hari & Rp 445,841,478 \\
Jatuh Tempo diatas 91 hari & $\operatorname{Rp~671,137,660}$ \\
TOTAL & $\mathbf{R p ~ 2 0 , 1 2 8 , 7 3 6 , 4 9 0}$ \\
\hline
\end{tabular}

Berdasarkan tabel di atas, saldo piutang usaha adalah sebesar Rp. 20,128,736,490. Jika dilihat dari data di atas bahwa saldo umur piutang berdasarkan tagihan yang sudah jatuh tempo mengalami penurunan yang artinya bahwa umur piutang usaha dapat berjalan atau berputar menjadi kas.

Tabel 3 Saldo Piutang Usaha Tahun 2016 PT.Cowell Development Tbk

\begin{tabular}{|c|c|}
\hline Umur Piutang usaha & Saldo Piutang Usaha \\
\hline Belum Jatuh Tempo & Rp 20,990,176,209 \\
\hline Jatuh Tempo 0-60 hari & $\operatorname{Rp} 4,120,836,036$ \\
\hline Jatuh Tempo 61-90 hari & $\operatorname{Rp} 55,388,489$ \\
\hline Jatuh Tempo diatas 91 hari & $\operatorname{Rp} 1,127,373,555$ \\
\hline TOTAL & Rp 26,177,729,544 \\
\hline
\end{tabular}

Berdasarkan tabel di atas, saldo piutang usaha adalah sebesar $\mathrm{Rp}$ 26,177,729,544 dengan saldo piutang usaha tersebut terdapat ada selisih piutang atas entitas anak perusahaan yang sebesar Rp. 116,044,745 yang dinyatakan bahwa piutang usaha dengan nominal tersebut atas entitsas anak perusahaan tidak dapat tertagih. Jika dilihat dari data di atas bahwa saldo umur piutang berdasarkan tagihan yang sudah jatuh tempo mengalami penurunan di jatuh tempo 61-90 hari sedangkan jatuh tempo diatas 91 hari mengalami kenaikan. 
Tabel 4 Saldo Piutang Usaha Tahun 2017 PT.Cowell Development Tbk

\begin{tabular}{cc} 
Umur Piutang usaha & Saldo Piutang Usaha \\
Belum Jatuh Tempo & $\operatorname{Rp~41,888,358,151}$ \\
Jatuh Tempo 0-60 hari & $\operatorname{Rp~40,704,482,375~}$ \\
Jatuh Tempo 61-90 hari & $\operatorname{Rp} 29,236,080,369$ \\
Jatuh Tempo diatas 91 hari & $\operatorname{Rp~3,618,360,801~}$ \\
TOTAL & $\mathbf{R p ~ 1 1 5 , 3 3 1 , 2 3 6 , 9 5 1}$ \\
\hline
\end{tabular}

Berdasarkan tabel di atas, saldo piutang usaha adalah sebesar $\mathrm{Rp}$. $115,331,236,951$ dengan saldo piutang usaha tersebut terdapat selisih piutang atas entitsas anak perusahaan yang sebesar Rp. $116,044,745$ yang dinyatakan bahwa piutang usaha dengan nominal tersebut atas entitsas anak perusahaan tidak dapat tertagih. Jika dilihat dari data di atas bahwa saldo umur piutang berdasarkan tagihan yang sudah jatuh tempo mengalami penurunan yang artinya bahwa umur piutang usaha dapat berjalan atau berputar menjadi kas.

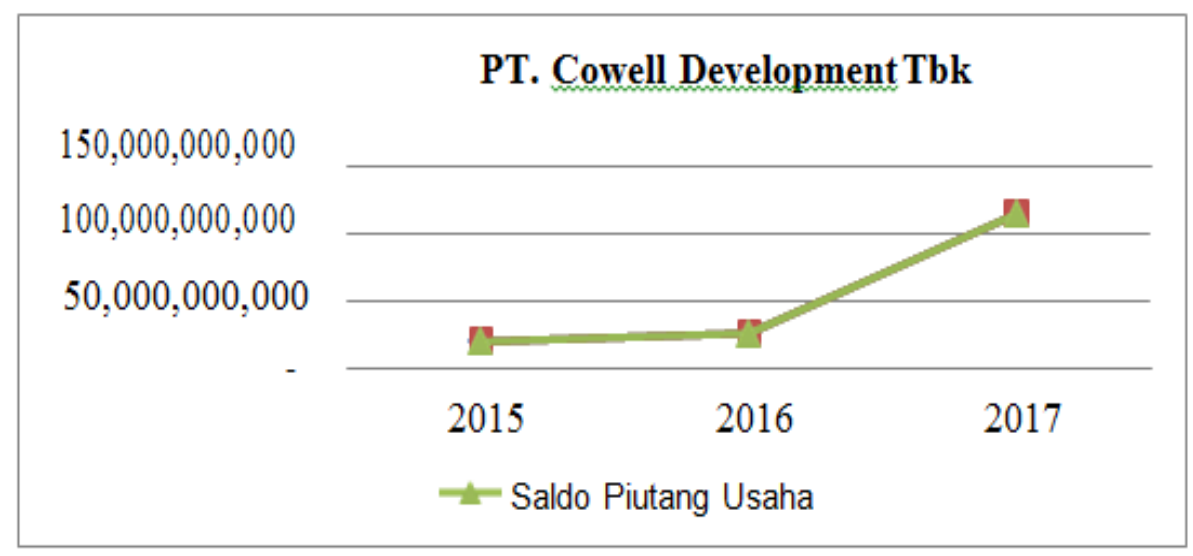

Gambar 1 Grafik saldo piutang usaha PT Cowell Development Tbk

Berdasarkan hasil rekapitulasi saldo piutang usaha terlihat bahwa pada tahun 2015 sampai dengan tahun 2017 saldo piutang usaha mengalami kenaikan pada PT Cowell Development Tbk. Data ini melalui perhitungaan grafik diambil berdasarkan saldo piutang usaha pertahun. Pada tahun 2015 saldo piutang usaha sebesar Rp 20,128,736,490. Di tahun 2016 saldo piutang usaha meningkat yaitu 
sebesar Rp. 26,177,729,544 dari tahun 2015 yaitu sebesar Rp $20,128,736,490$ dan artinya bahwa PT Cowell Development Tbk masih dalam perputara piutangnya masih berjalan dengan baik, sedangkan pada tahun 2017 saldo piutang usaha meningkat yaitu sebesar Rp. $115,331,236,951$ dari tahun 2016 yaitu sebesar Rp. 26,177,729,544 yang artinya saldo piutang mengalami kenaikan begitu juga dengan saldo kas juga mengalami kenaikan sehingga hal yang wajar karena saldo piutang usaha yang meningkat dan saldo kas pun meningkat bahwa saldo piutang masih berjalan dengan baik. Metode umur piutang usaha dikelompokkan berdasarkan pada masing-masing karakteristik umur yang berarti adanya pengelompokan piutang usaha ke dalam kategori yang berdasarkan atau tanggal jatuh tempo piutang usaha. Karakteristik umur piutang usaha disini dapat diklasifikasikan menjadi: belum jatuh tempo, telah jatuh tempo 0-60 hari, telah jatuh tempo 61-90 hari, telah jatuh tempo diatas 91 hari. Lamanya umur piutang usaha yang telah jatuh tempo merupakan lamanya hari mulai saat piutang usaha tersebut jatuh tempo hingga menjadi laporan umur piutang usaha (aging schedule).Berdasarkan umur piutang usaha perusahaan yang sudah lama jatuh tempo sangat kecil kemungkinannya untuk dapat ditagih Hery (2016). Karena jika terlalu besar jumlah saldo piutang tak tertagih ataupun jumlah saldo piutang usaha tidak efektifnya pengendalian terhadap menajer yang memutuskan kredit atau tidak efektifnya bagian piutang usaha yang pada akhirnya menimbulkan kerugian bagi perusahaan. Piutang usaha diharapkan dapat tertagih dalam satu tahun atau siklus usaha normal diklasifikasikan sebagai aset lancar. Seluruh piutang usaha digolongkan sebagai aset lancar tanpa memandang jangka waktu tertagihnya. Dengan demikian jumlah piutang usaha yang jangka waktu penagihannya lebih satu tahun atau siklus usaha normal harus diungkapkan dalam catatan atau laporan keuangan. Dalam penagihanpiutang yang terjadi pada PT Cowell Development Tbk pihak manajemen perusahaan mempunyai beberapa metode dalam 
mengendalikan piutang tak tertagih yang terjadi pada perusahaan. Metode yang digunakan pada PT Cowell Development Tbk adalah sebagai berikut:

a. Followup by telp

Apabila customer belum melakukan pembayaran atas tagihan yang sudah jatuh tempo maka dilakukan followup by telp karena untuk reminder customer agar segera melakukan pembayaran atas tagihan yang sudah jatuh tempo.

b. Surat Peringatan

Apabila customer masih belum melakukan pembayarannya maka dalam waktu telat 1 bulan maka akan dikeluarkan surat peringatan atas tagihan yang sudah jatuh tempo. c. Mendatangi langsung Penyewa atau Customer Apabila customer masih belum melakukan kewajibannya dalam melakukan pembayaran maka dilakukan mendatangi penyewa atau customer untuk ditindaklajuti atas kewajiban penyewa belum melakukan kewajibannya untuk melunasi tagihan yang sudah jatuh tempo.

Mengukur efektivitas pengendalian internal piutang usaha

Receivable turn over (RTO) menunjukan suatu angka yang menunjukan berapa kali (dalam ratarata) suatu perusahaan melakukan tagihan atas piutangnya pada suatu periode tertentu. Adapun hasil perhitungan dari perputaran piutang usaha adalah sebagai berikut:

1. Tahun 2015

Perputaran Piutang Usaha $=\frac{583,329,689,427}{20,426,030,636}=28.56$

2. Tahun 2016

$$
\text { Perputaran Piutang Usaha }=\frac{570,072,055,705}{23,153,233,017}=24.62
$$


3. Tahun 2017

$$
\text { Perputaran Piutang Usaha }=\frac{525,324,518,118}{70,754,483,247}=7.42
$$

Tabel 5 Hasil perhitungan receivable turn over (RTO)

\begin{tabular}{c|cccc}
\hline \multirow{2}{*}{ Tahun } & Penjualan kredit & $\begin{array}{c}\text { Rata-Rata Piutang } \\
\text { usaha }\end{array}$ & RTO & Perubahan \\
\cline { 1 - 5 } & $(\mathbf{R p})$ & $(\mathbf{R p})$ & $($ Kali) & RTO \\
2015 & $583,329,689,427$ & $20,426,030,632$ & 28.56 & - \\
2016 & $570,072,055,705$ & $23,153,233,017$ & 24.62 & 3.94 \\
2017 & $525,324,518,118$ & $70,754,483,247.5$ & 7.42 & 17.2 \\
\hline
\end{tabular}

Dari data di atas menunjukan bahwa kinerja RTO mengalami penurunan dari tahun ke tahun.Hal ini ditunjukan pada hasil RTO tahun 2015 sebesar 28.56 kali. Pada tahun 2016 terjadi penurunan RTO yaitu 24.62 kali atau menurun 3.94 dari tahun sebelumnya. Pada tahun berikutnya, yaitu ditahun 2017 terjadi penurunan RTO sebesar 7.42 atau menurun 17.2 dari tahun sebelumnya. Dari hasil tabel Average collection period (ACP) perhitungan RTO PT Cowell Development Tbk sudah maksimal dalam memperbaiki kinerja piutang usahanya dan dapat mengurangi dengan seminimal mungkin jumlah piutang tak tertagihnya, karena makin tinggi perputaran piutang, maka piutang yang dapat ditagih oleh perusahaan semakin banyak. Sehingga akan memperkecil adanya piutang yang tak tertagih dan memperlancar arus kas.

1. Tahun 2015

$$
\text { Rata }- \text { Rata Jangka Waktu Penagihan }=\frac{360 \text { Hari }(1 \text { Tahun })}{28.56}=12
$$

2. Tahun 2016

$$
\text { Rata }- \text { Rata Jangka Waktu Penagihan }=\frac{360 \text { Hari }(1 \text { Tahun })}{24.62}=14
$$


3. Tahun 2017

$$
\text { Rata }- \text { Rata Jangka Waktu Penagihan }=\frac{360 \text { Hari }(1 \text { Tahun })}{7.42}=48
$$

Tabel 6 Hasil perhitungan receivable turn over (RTO)

\begin{tabular}{cccc}
\hline Tahun & RTO & ACP Hari & $\begin{array}{l}\text { Perubahan } \\
\text { ACP }\end{array}$ \\
2015 & 28.56 & 12 & - \\
2016 & 24.62 & 14 & -2 \\
2017 & 7.42 & 48 & -34 \\
\hline
\end{tabular}

Dari hasil tabel di atas terlihat tingkat ACP perusahaan sangat dipengaruhi oleh tingkat RTO perusahaan, semakin cepat perputaran piutang usaha RTO semakin kecil jumlah harinya maka akan semakin baik, artinya perusahaan mampu menagih dengan cepat setiap piutang usahanya. Tingkat ACP yang terbaik pada tahun 2015, yaitu sebesar 12 hari, di mana semakin kecil jumlah harinya maka tingkat perputaran piutang usahanya semakin besar. Sedangkan tingkat ACP perusahaan yang terendah adalah pada tahun 2017 di mana tingkat ACP yang dihasilkan mencapai 48 hari, dimana semakin tinggi tingkat perputaran piutang usahanya semakin rendah, yaitu 7.42 kali. Hal ini menunjukan kinerja piutang usahanya sudah dilakukan dengan baik.

Aging of account receivable

Suatu angka yang menunjukan untuk mengukur dipisah berdasarkan aging atau umur overdue piutang usaha.

Tabel 7 hasil perhitungan Aging of account receivable

\begin{tabular}{lrrr}
\hline \multicolumn{1}{c}{ Bucket } & $\mathbf{2 0 1 5}$ & $\mathbf{2 0 1 6}$ & \multicolumn{1}{c}{$\mathbf{2 0 1 7}$} \\
Aging not yet due & $86.26 \%$ & $80.18 \%$ & $36.32 \%$ \\
Aging 0-60 & $8.18 \%$ & $15.74 \%$ & $35.29 \%$ \\
Aging 61-90 & $2.21 \%$ & $0.21 \%$ & $25.34 \%$ \\
Aging $91+$ & $3.33 \%$ & $4.30 \%$ & $3.13 \%$ \\
\hline
\end{tabular}


Aging not yet due, terbaik ditahun 2016 ke 2017 ada penurunan presentase aging yang terjadi secara signifikan yaitu sebesar $43.86 \%$. Aging 0-60 hari, terbaik ditahun 2015 ke 2016 ada kenaikan presentase aging yang terjadi yaitu sebesar 7.56\%. Aging 61-90 hari, terbaik ditahun 2015 ke 2016 ada penurunanpresentase aging yang terjadi yaitu sebesar $2 \%$. Aging $91+$ hari, terbaik ditahun 2016ke 2017 adanya penurunan presentase aging

\section{SIMPULAN}

Berdasarkan penelitian yang telah dilakukan oleh penulis maka dapat disimpulkan bahwa pengendalian internal piutang usaha sudah diterapkan dengan benar dalam pengendalian piutang terhadap penagihan piutang arus kas, saldo jumlah piutang usaha setiap tahun masih meningkat, dengan demikian bahwa saldo kas pun meningkat dan membuktikan bahwa PT Cowell Development Tbk masih dalam keadaan perputaran piutang dengan baik. Penagihan piutang usaha sudah yang terjadi yaitu sebesar $1.17 \%$.

Dari tabel aging of account receivable di atas menunjukan bahwa rasio aging of account receivable mengalami perbaikan dari tahun ke tahun yaitu presentase aging dari tahun ke tahun mengalami penurunan dengan demikian perputaran piutang dapat berjalan dengan baik untuk menjadi kas. Hal ini menunjukan bahwa kualitas penagihan mengalami perbaikan, pengendalian internal piutang usaha yang dilakukan oleh perusahaan.

dijalankan sesuai dengan prosedur yang ditentukan oleh manajemen perusahaan. Penagihan piutang dengan cara penagihan secara langsung ke customer yang paling efektif untuk menurangi piutang tak tertagih. PT Cowell Development Tbk sudah dilakukan dengan efektif dalam meminimal saldo piutang usaha. Ada beberapa hal yang dapat disimpulkan dari hasil penelitian tersebut antara lain berdasarkan perhitungan yang dilakukan dengan metode receivable turn over (RTO) PT Cowell Development Tbk sudah maksimal dalam memperbaiki 
kinerja piutang usahanya dan dapat mengurangi dengan seminimal mungkin jumlah piutang tak tertagihnya, karena makin tinggi perputaran piutang, maka piutang yang dapat ditagih oleh perusahaan semakin banyak. Sehingga akan memperkecil adanya piutang yang tak tertagih dan memperlancar arus kas.perusahaan mencapai titik tertinggi yaitu pada tahun 2015 sebesar 28.56 kali dan sebaliknya RTO terendah ditahun 2017 sebesar 7.42 kali. Dapat dilihat bahwa perputaran piutang perusahaan dari tahun ketahun mengalami penurunan. Semakin cepat piutang kembali menjadi kas, berarti semakin tinggi perputaran piutang. Berdasarkan perhitungan yang dilakukan dengan metode average collection period (ACP) Tingkat ACP yang terbaik pada tahun 2015, yaitu sebesar 12 hari, di mana semakin kecil jumlah harinya maka tingkat perputaran piutang usahanya semakin besar. Sedangkan tingkat $\mathrm{ACP}$ perusahaan yang terendah adalah pada tahun 2017 di mana tingkat ACP yang dihasilkan mencapai 48 hari, dimana semakin tinggi tingkat perputaran piutang usahanya semakin rendah, yaitu 7.42 kali. Hal ini menunjukan kinerja piutang usahanya sudah dilakukan dengan baik di PT Cowell Development Tbk. Berdasarkan perhitungan yang dilakukan dengan metodeaging of account receivable bahwa adanya penurunan presentase aging di setiap tahunnya dengan demikian perputaran piutang dapat berjalan dengan baik untuk menjadi kas. Hal ini menunjukan bahwa kualitas penagihan mengalami perbaikan, pengendalian internal piutang usaha yang dilakukan oleh perusahaan. Berdasarkan kesimpulan tersebut maka saran yang diberikan kepada PT Cowell Development Tbk adalah perusahaan untuk lebih memperhatikan tindakan/kegiatan dalam penagihan piutang untuk lebih aktif dalam penagihan piutang, agar dapat meminimalkan jumlah saldo piutang usaha. Melakukan aktivitas pengendalian dengan cara pemisahan fungsi operasional dan penyimpanan dari fungsi akuntansi. Fungsi operasional memiliki wewenang untuk melaksanakan kegiatan dan setiap kegiatan dalam perusahaan memerlukan otoritas dari manajer. Sedangkan fungsi akuntasi adalah 
fungsi yang memiliki wewenang untuk mencatat peristiwa keuangan perusahaan. Suatu fungsi tidak boleh diberi tanggung jawab penuh untuk semua tahapan karena untuk

\section{DAFTAR PUSTAKA}

Arens, A \& Beasley. (2010).

Auditing dan Jasa Assurance (terjemahan). Edisi 15. Jakarta: Erlangga.

Baridwan, Z. (2004). Intermediate Accounting "Pengantar Akuntansi" . Buku 2. Edisi 21. Jakarta: Salemba Empat.

Baridwan, Z. (2008). Sistem

Akuntansi Penyusutan Prosedur dan Metode. Edisi 5. Yogyakarta: BPPE.

Weygandt, D \& Terry D, W. (2008). Akuntansi Intermediate. Edisi 12. Jakarta : Erlangga.

Dwi, M., \& dkk. (2012). Akuntansi Keuangan Menengah Berbasis PSAK. Buku 1. Jakarat: Salemba Empat.

Harahap, S. S. (2002). Analisis

Krisis Atas Laporan Keuangan. Jakarta: Raja Grafindo Persada.

Hayati. (2011). Buku Pratikum Vertebrata. Jakarta: Erlangga.

Hery. (2013). Auditing (Pemeriksaan Akuntansi 1). Cetakan Pertama. Jakarta: CAPS. mencegah kesalahan dan kecurangan dalam melaksanakan tugas yang dibebankan kepada seseorang.

John, D., \& Jordan, E. G. (1996).

Baarron's Dictionary of Finance \& Investment Terms. Amerika: Tandem Library.

Kasmir. (2010). Pengantar

Manajemen Keuangan . Jakarta: Kencana Prenanda Media Group.

Keown, J. (2008). Manajemen

Keuangan Prinsip dan Penerapan. Yogyakarta: Andi.

Munir. (2005). Manajemen Sumber

Daya Manusia. Jakarta: Erlangga.

Riyanto, B. (2004). Dasar-Dasar

Pembelajaran Perusahaan. Edisi 4. Yogyakarta: BPFC.

Soemarso S, R. (2002). Akuntansi

Status Pengantar. Buku 1. Edisi 5. Jakarta: Salemba Empat.

Stice, E. K., \& Skousen, J. D.

(2009).

Akuntansi Keuanagan Menengah. Buku 2. Edisi 16. Edisi Bahasa Indonesia Terjemahan Oleh Ali Akbar. Jakarta : Salemba Empat. 
Sujarweni, W. (2015). Akuntansi

Manajemen. Yogyakarta: Pustaka Baru Press.

Sukrino, A. (2012). Auditing

(Petunjuk Praktis Pemeriksaan Akuntan oleh Akuntan Publik). Edisi 4. Jakarta: Salemba Empat.

Syahyunan. (2004). Laporan

Keuangan. Jakarta:

Rajawali.

Syakur, S. A. (2015). Intermediate

Accounting. Jakarta: A V Publisher. 